IRSH 62 (2017), pp. 389-4I9 doi:10.1017/S0020859017000323

(C) 2017 Internationaal Instituut voor Sociale Geschiedenis

\title{
"I Thought of It at Work, in Ostend": Urban Artisan Labour and Guild Ideology in the Later Medieval Low Countries*
}

\author{
JAN DUMOLYN \\ Ghent University, Department of History \\ Henri Pirenne Institute for Medieval Studies \\ Sint-Pietersnieuwstraat 35, 9000 Ghent, Belgium \\ E-mail: jan.dumolyn@ugent.be
}

\begin{abstract}
From the twelfth and certainly from the thirteenth century onwards, a social group of artisans with their own political and economic aspirations can be clearly delineated in Netherlandish towns. Bound through common skilled work, they made up a distinctive group with a self-image and a developing political vision and economic programme. Their "guild ideology" is increasingly clearly expressed in the sources they produced from the fourteenth century onwards as a self-confident group in urban society. Labour, certainly when organized within guild structures, was the cornerstone of community life, cultural experiences, and practical ethics. Even though there were socioeconomic differences among guildsmen and many geographical and chronological variations in the degree of political power they wielded, the ideal of artisan ideology in the late medieval Low Countries was one of a community of brotherly love and charity centred on the value of skilled labour.
\end{abstract}

While working in the Flemish coastal town of Ostend, the master mason Anthonis de Roovere (c.I430-I 482) composed a poem about obedience. It is the first literary text in Dutch in which a writer explicitly identified himself as a worker. Anthonis hailed from the commercial metropolis of Bruges, during a time in which the standard of living of the most prosperous artisans was at its peak. ${ }^{\mathrm{I}} \mathrm{He}$ was also a respected rederijker, a member of the

\footnotetext{
* I am deeply indebted to Catharina Lis and Hugo Soly for their inspiring comments on this text and for our conversations on medieval guilds in general. Bert De Munck, Shennan Hutton, and Thomas Donald Jacobs also provided useful critiques and suggestions for this paper.

I. Jean-Pierre Sosson, "Les XIVe et XVe siècles. Un 'âge d'or de la main-d'œuvre'? Quelques réflexions à propos des anciens Pays-Bas méridionaux", Publications du Centre Européen d'Études bourguignonnes, 27 (1987), pp. 17-38; Erik Thoen and Tim Soens, "Vegetarians or
} 
Holy Ghost rhetoricians' guild. These literary corporations, a prominent feature of urban culture in the later medieval Low Countries, mostly united well-off guild masters, who expressed their social and religious values through poetry, playwriting, and urban historiography. Anthonis probably wrote this poem for an ordination or consecration, frequent commissions for such rhetoricians. ${ }^{2} \mathrm{He}$ emphasized that obedience, as demonstrated by Christ, was more valuable than any worldly goods. A servant should obey his master, and, while working, journeymen or apprentices ought to listen to their craft superiors. Obedience not only nourishes peace in the individual soul and between men, it is essential for learning a trade. ${ }^{3}$

While earlier scholars have judged him a clumsy, stodgy writer, Anthonis's repetitive lamentations and socio-religious moralizing reveal the worldview of the late medieval Low Countries master guildsman perhaps better than any other source. In fact, he may have been the most eloquent spokesman of the fifteenth-century artisan milieu in Flanders. ${ }^{4} \mathrm{He}$ did not refer to his manual labour in general terms alone, and references to his work were more than a literary topos. In several texts, Anthonis provided specific moral instructions centred on the values of honest and skilled work; these guidelines honoured thrift, modesty, fairness, and criticized the selfish rich. The mason stressed that to be happy in old age, a man must maintain a "good regime" for body and soul. Do not incur debts, say your prayers, and build up a secure source of income. Be humble, patient, unenvious, and maintain a good reputation. While this emphasis on vices and virtues was hardly original, the connections between an essentially religious and moralizing discourse and the practical, common sense of the late medieval artisan are striking. "Oh deceptive weights, oh false scales", he deplored. Was there any hope left in a world ruled by false appearances and lies?'

Carnivores? Standards of Living and Diet in Late Medieval Flanders", in Simonetta Cavaciocchi (ed.), Le interazioni fra economia e ambiente biologico nell'Europa preindustriale. Secc. XIIIXVIII (Florence, 2010), pp. 495-527.

2. Anne-Laure van Bruaene, "Brotherhood and Sisterhood in the Chambers of Rhetoric in the Southern Low Countries", The Sixteenth Century Journal, 36:1 (2005), pp. I I-35; on the predominantly middle-class background of the rhetoricians, refuting previous views on their supposed elite nature, see idem, Om beters wille. Rederijkerskamers en de stedelijke cultuur in de Zuidelijke Nederlanden (I400-1650) (Amsterdam, 2008), pp. 43, 51, I57-162, as well as Jan Dumolyn, "Het corporatieve element in de Middelnederlandse letterkunde en de zogenaamde laatmiddeleeuwse burgermoraal”, Spiegel der Letteren, 56:2 (2014), pp. I 23-I 54.

3. Jacobus Johannes Mak (ed.), De gedichten van Anthonis de Roovere (Zwolle, 1955), pp. I 27-I 29.

4. A more recent appraisal of him by Johan Oosterman, "Anthonis De Roovere. Het werk. Overlevering, toeschrijving, plaatsbepaling", Jaarboek Koninklijke Soevereine Hoofdkamer van Retorica "De Fonteine" te Gent, 45-46 (1995-1996), pp. 29-140; ibid., 46-47 (1997-1998), pp. 9-88.

5. Mak, De gedichten, pp. 252-253, 314. 
This directly related to the ethos of fairness and quality control in artisanal production and commerce. At times, Anthonis also deployed political language, and while he believed the meek were blessed, there were limits to his acquiescence. On some occasions he adopted a bitter tone, ruthlessly chastising the rich and powerful "who destroy the poor" as he lamented the general social injustice of his time. ${ }^{6}$

In another complaint, Anthonis deplored the fact that "the lords who ride their high horses" must be obeyed, while men in mended shoes drudged for them. He then imagined an ironic world in which everyone is honest, rulers always just, lawyers never lie, merchants and artisans do not cheat, and the "old" customary laws, so dear to the craft guilds, are always respected. However, the grim reality was that "charity and loyalty are both corpses". And in yet another deeply vitriolic text, Anthonis addressed toiling ploughmen and diggers: you will have no silver but carry on, while your sweat is blessed. You might have to risk your lives, and your wages are small, but keep the faith. You might not be able to buy annuities, but your diligent labour is highly esteemed. Do not complain about your hard work, and even if you don't have a marrowbone to suck on, you will have bread and mush in your old age. It is sometimes hard to distinguish between his bitter irony and his trust in God, and thus know whether he was really defying the social order. ${ }^{7}$

\section{THE DEBATE ON GUILD IDEOLOGY}

In recent decades, the number of studies on craft guilds has greatly increased. The majority of economic historians now argue that guilds played a more beneficial economic role than was once assumed after Adam Smith began vilifying them as obstructions to freedom and progress. Stephan R. Epstein showed how they stimulated technological change and diffusion through migrant labour and provided transferable skills through apprenticeship. Guilds also enforced quality standards: by reducing search and information costs they decreased information asymmetries in marketplaces; they protected their members from expropriation by merchant elites; they contributed to innovation and efficiency; and they managed conflicts between rival members. ${ }^{8}$ Although these recent approaches, inspired by the "New Institutional Economics", have thus been

6. Ibid., p. 322 .

7. Ibid., pp. $335-338,34 \mathrm{I}-343$.

8. Stephan R. Epstein, "Craft Guilds, Apprenticeship, and Technological Change in PreIndustrial Europe", The Journal of Economic History, 58:3 (1998), pp. 684-7I 3; idem and Maarten Prak (eds), Guilds, Innovation, and the European Economy, I400-I 800 (Cambridge, 2008); Bert De Munck, Steven L. Kaplan, and Hugo Soly (eds), Learning on the Shop Floor: Historical Perspectives on Apprenticeship (New York, 2007). Counterarguments, however, have been 
instrumental in salvaging guilds as institutions, they tend to neglect guild practices and discourses outside the realm of "the economic", and the ideological utterances of guildsmen have received far less systematic empirical scrutiny. ${ }^{9}$

As Steven A. Epstein remarked in 199r: "what in other fields is called labour history remains for the Middle Ages largely unwritten". ${ }^{\circ}$ It remains a widespread misconception that medieval people perceived labour negatively, and that the development of a "work ethic" was an early modern phenomenon related to a gradual advancement of capitalist relations of production. In fact, the sources tell quite a different story. Already in the fourth century, St Augustine wrote that human labour was a virtuous and dignified activity inherent in divine order. The Church Father praised the results of the industria humana. Work itself was not a punishment for The Fall; the penalty was the burden labour placed on workers. ${ }^{\text {II }}$ And by the Late Middle Ages, manual work was considered a morally and socially worthwhile activity. ${ }^{\mathrm{I} 2}$ The urban craft guilds of the medieval Netherlands (ambocbten or ghilden in Middle Dutch and mestiers in Middle French) in which skilled workers were organized formed strong corporative communities, and guildsmen like Anthonis sometimes left sources indicating how they valued their own work and that of artisans in general.

Yet, since the I970s, the socio-political analysis of such "corporate idioms", "artisan languages", or "guild ideologies" - terms that are mostly used interchangeably and refer to the social and political discourses uttered by artisans, and more specifically the ways they imagine and represent themselves and their corporations - has almost exclusively been studied by specialists of early modern guilds, who usually have many more sources at their disposal. Sewell located a "language of labour" at the end of the Ancien Régime in which old corporatist ideas and a rising modern class consciousness interacted and heralded the coming revolution and

formulated by Sheilagh Ogilvie, "Guilds, Efficiency, and Social Capital. Evidence from German Proto-Industry”, The Economic History Review, 57:2 (2004), pp. 286-333.

9. An exception grounded in a more classical form of political economy is Hugo Soly, "The Political Economy of European Craft Guilds: Power Relations and Economic Strategies of Merchants and Master Artisans in the Medieval and Early Modern Textile Industries", International Review of Social History, 53: S26 (2008), pp. 45-7I, and a strong case for the importance of guilds outside the economic sphere was made by Gervase Rosser, "Crafts, Guilds and the Negotiation of Work in the Medieval Town”, Past and Present, I 54 (1997), pp. 3-3 I.

ı०. Steven A. Epstein, Wage Labor and Guilds in Medieval Europe (Chapel Hill, NC, I991), p. 6.

I I. See the recent seminal work by Catharina Lis and Hugo Soly, Worthy Efforts: Attitudes to Work and Workers in Pre-Industrial Europe (Boston, MA, 201 2), p. I04.

I 2. Christopher Dyer, "Work Ethics in the Fourteenth Century", in James Bothwell, P.J.P. Goldberg, and W.M. Ormrod (eds), The Problem of Labour in Fourteenth-Century England (Woodbridge, 2000), pp. $2 \mathrm{I}-42$. 
transformation. ${ }^{13}$ Developing an in-depth analysis of such Ancien Régime languages of labour, Kaplan insisted that the guild identity of eighteenthcentury Paris masters was primarily social and cultural rather than economic. They thought their corporations were worthy institutions and they associated specific ideological values with mastership. Guild membership had become a form of social classification that offered a fixed position in society, and guild ideology was a subjective translation of this social taxonomy. ${ }^{14}$ But Cerutti, a specialist of early modern guild languages in Turin, found Kaplan's interpretation too naively accepting of the masters' self-interested rhetoric. Instead, she argued for the importance of guild privileges as a means for individuals and their family networks to gain access to scarce resources, viewing the language of corporate associations as much more instrumental rather than as an internalized ideology. Moreover, she stressed that urban labour was only partly corporately organized, and so guild ideologies did not encompass all languages of work. ${ }^{\text {is }}$

Another attempt at re-evaluating such "extra-economic" aspects appears in Farr's study of the artisans of sixteenth-century Dijon. He demonstrated that manual work, especially when skilled, was also essential in forging a system of human relations. Guild discourses about artisan labour and its organization were about more than creating institutions for the growth of markets and production. ${ }^{16}$ For Farr, "honour" was a central ideological category of corporate artisan discourses, along with community, brotherhood, family, charity, reputation, manliness, discipline, skill, and status. These ideological categories belonged to the habitus of artisans and were also used as tools of hierarchy and control. ${ }^{17}$ However, the term "honour" almost never appears in guild sources from the medieval Low Countries, ${ }^{18}$

I3. William H. Sewell, Jr, Work and Revolution in France: The Language of Labor from the Old Regime to ${ }_{1} 848$ (Cambridge, I980), pp. 3-5; see also Steven L. Kaplan, "Idéologie, conflits et pratiques politiques dans les corporations parisiennes au XVIIIe siècle”, Revue d'Histoire Moderne et Contemporaine, 49: I (2002), pp. 5-55.

I4. Steven L. Kaplan, "Social Classification and Representation in the Corporate World of Eighteenth-Century France: Turgot's 'Carnival'”, in idem and Cynthia J. Koepp (eds), Work in France: Representations, Meaning, Organization, and Practice (Ithaca, NY, I986), pp. 176-228. I s. Simona Cerutti, La ville et les métiers. Naissance d'un langage corporatif (Turin, $I 7^{e}-I 8^{e}$ siècles) (Paris, 1990), p. I 5 .

16. James R. Farr, Hands of Honor: Artisans and their World in Dijon, I550-1650 (Ithaca, NY, I988), p. I3; Lis and Soly, Worthy Efforts.

17. Farr, Hands of Honor, pp. I0-I I, I4-21, I25; idem, Artisans in Europe, 1300-1914 (Cambridge, 2000), pp. 2 I-23, 229-230.

I8. Nor did later medieval guild records in the Low Countries distinguish between "honourable work" and "non-honourable" activities, as was sometimes the case, for instance with the linen weavers in some German towns, who were considered "impure" and marginal. See Erich Maschke, "Die Unterschichten der mittelalterlichen Städte Deutschlands", in idem and Jürgen Sydow (eds), Gesellschaftliche Unterschichten in den südwestdeutschen Städten (Stuttgart, I967), pp. I3-15, and Glenn M. Bulow, "Leineweber(innen). Handwerker zwischen Zunftausschluss, 
and there are other significant differences as well. Artisans in sixteenthcentury Dijon, or in Cerutti's seventeenth- and eighteenth-century Turin, were a far less important socioeconomic and political force than those in fifteenth-century Flanders. The same problem with such comparisons applies to guilds in medieval England - recently excellently investigated by Rosser. He generally considers "crafts" as just one class of "guilds", an observation that may describe the situation in later medieval England but which does not do justice to the prominence of crafts in the Low Countries, which far exceeded that of English craft guilds. ${ }^{19}$ While taking into account various insights from these debates, I intend to defend a position closer to Kaplan's point of view, arguing for the presence of a strong and selfconscious craft guild ideology with labour as one of its central elements.

\section{CRAFT GUILDS IN THE LATER MEDIEVAL LOW COUNTRIES}

Rosser is certainly right in pointing out that in many regions of Europe it is hard to distinguish between medieval religious confraternities and professional lay corporations that also had religious functions. ${ }^{20}$ During the twelfth and thirteenth centuries, for which we have only fragmentary sources, Flemish guilds sometimes first appeared in the form of religious confraternities with members in the same trade, and they were usually controlled by patrician urban governments. However, with social and political emancipation, craft guilds soon developed into specialized and specific corporations. In fact, by the fourteenth century, as they were rising to political power in major industrial towns like Ghent or Bruges, most craft guilds developed separate religious confraternities (ghilden or broederscepen) with their own leaders, but remained closely linked to the craft structure, with overlapping membership. And although there were also numerous independent religious guilds, the general picture emerging from the sources is that these were less important in structuring social life in the Netherlands than elsewhere. Only in French-speaking Flanders and Artois, where the urban revolts of the early fourteenth century failed, did

Verketzerung und Armutsspott”, in Bernd-Ulrich Hergemöller (ed.), Randgruppen der spätmittelalterlichen Gesellschaft (Warendorf, 2001), pp. 198-2 18.

19. Gervase Rosser, The Art of Solidarity in the Middle Ages: Guilds in England I250-I550 (Oxford, 2015), pp. I05, I I I, I I I-I 52. Crafts in England also played considerably less autonomous roles in labour regulations than was the case in regions such as Flanders, Brabant, or Liège. See Sarah Rees Jones, "Household, Work and the Problem of Mobile Labour: The Regulation of Labour in Medieval English Towns", in Bothwell et al., The Problem of Labour in FourteenthCentury England, pp. I33-1 53 .

20. This was first systematically formulated by Gilles Gérard Meersseman, Ordo fraternitatis. Confraternite e pietà dei laici nel medioevo, 3 vols (Rome, I977), I, p. 9. 
such confraternities remain important in organizing labour as well. ${ }^{21}$ Thus, while not all urban labour was corporately organized in the Netherlands, it is clear that neither religious confraternities, nor any other kind of parish or neighbourhood structure could compete against the craft guilds' impact in organizing daily social relations, in offering possibilities for social integration and strategies for relief and solidarity, let alone in exerting political and ideological influence.

In Turin, Cerutti noted, a proper "language of labour" became more prominent only once the guilds had achieved an important political position. Arising in the sixteenth century, they became politically important in the eighteenth - rather late compared with most other European regions. ${ }^{22}$ As has been well established, craft guilds in the Low Countries became integral parts of their cities' body politic much earlier. Between c. 1275 and c. I 540 , crafts engaged in episodic waves of revolts, obtaining positions in various urban governments between $\mathrm{I}_{3} 00$ and $\mathrm{I}_{3} 60$. During this process, they developed a genuine political tradition and ideological discourse of their own. ${ }^{23}$ Their political strength is also explained by the fact that, certainly prior to the Burgundian-Habsburg unification of the Netherlands, the politics of Flemish and Brabantine towns were relatively unconstrained

21. Carlos Wyffels, De oorsprong der ambachten in Vlaanderen en Brabant (Brussels, I951), pp. 55, I24-I42; Paul Trio, "Les confréries comme expression de solidarité et de conscience urbaine aux Pays-Bas à la fin du Moyen Âge”, in Hanno Brand, Pierre Monnet, and Martial Staub (eds), Memoria, communitas, civitas. Mémoire et conscience urbaines en Occident à la fin $d u$ Moyen Âge (Ostfildern, 2003), pp. I 3 I-I 4 I; Paul Trio, "The Social Positioning of Late Medieval Confraternities in Urbanized Flanders", in Monika Escher-Apsner (ed.), Medieval Confraternities in European Towns (Frankfurt, 2009), pp. 99-1 10. In Flanders, as in many other regions outside England, craft guilds were also distinguished from religious confraternities by the terms used to denote them. See also Franz Irsigler, "Zur Problematik der Gilde- und Zunftterminologie”, in Berent Schwineköper (ed.), Gilden und Zünfte. Kaufmännische und gewerbliche Genossenschaften im frühen und hohen Mittelalter (Sigmaringen, 1985), pp. 53-70.

22. Cerutti, La ville, pp. I7-18.

23. Jan Dumolyn and Jelle Haemers, "Patterns of Urban Rebellion in Medieval Flanders", Journal of Medieval History, 3 I:4 (2005), pp. 369-393. Jan Dumolyn, "Guild Politics and Political Guilds in Fourteenth-Century Flanders", in idem et al. (eds), The Voices of the People in Late Medieval Europe: Communication and Popular Politics (Turnhout, 2014), pp. I 5-48. Studying towns in the Holy Roman Empire where guilds also achieved a strong governmental role, such as Cologne and Strasbourg, Schulz coined the concept of the politische Zunft, or "political guild"; Knut Schulz, "Die politische Zunft. Eine die spätmittelalterliche Stadt prägende Institution?”, in Wilfried Ehbrecht (ed.), Verwaltung und Politik in Städten Mitteleuropas. Beiträge zu Verfassungsnorm und Verfassungswirklichkeit in altständischer Zeit (Cologne, 1994), p. 3. See also Marc Boone, "La Construction d'un républicanisme urbain. Enjeux de la politique municipale dans les villes flamandes au bas Moyen Âge", in Denis Menjot and Jean-Luc Pinol (eds), Enjeux et expressions de la politique municipale (XIIe-XXe siècles) (Paris, I997), pp. 4I-60. For the Italian comparison, see for instance Roberto Greci, "Corporazioni e politiche cittadine. Genesi, consolidamento ed esiti di un rapporto (qualche esempio)", in idem, Corporazioni e mondo del lavoro nell'Italia padana medievale (Bologna, I 988), pp. 92-I 28. 
by larger political forces - unlike the situation in, for instance, France, England, or Castile, where royal authority formed a direct or indirect brake on the political activities of urban guilds. In the prince-bishoprics of Liège and Utrecht, artisans were also able to assume leading political roles as counterweights to the ecclesiastical lords. ${ }^{24}$

Hence, when attempting comparisons, the exceptional nature of the guilds in the industrial towns of the late medieval Low Countries cannot be emphasized enough. Moreover, to my knowledge, medieval literature produced few such examples of writers explicitly identifying as manual workers. Nor was it a coincidence that a mason like Anthonis wrote in the fifteenth-century commercial metropolis of Bruges. This region represented the peak of prosperity, urbanization, and guild strength in this period, where the guild structure had become the guiding principle of social organization for the largest segment of the male urban population, especially in the major industrial centres that produced commodities for international markets. Small entrepreneurs, retailers, and workers were often highly skilled, more or less literate, and politically conscious. ${ }^{25}$

The political weight of the Low Countries crafts corresponded with the exceptional importance, by medieval standards, of their artisanal industries, especially cloth production. In the thirteenth century, the textile industry was still firmly dominated by merchant entrepreneurs who controlled the means of production and the supply of raw materials and paid artisans piece wages. However, after the revolts around the $\mathrm{I}_{302}$ Battle of Courtrai that marked the victory of Flemish guildsmen over the King of France and his patrician allies, some of the economic power shifted to the "drapers" (or "clothiers"), small, independent entrepreneurs who belonged to the textile guilds. Guild masters could now hire other artisans as subcontractors and sell the finished products for a larger profit. Ultimately, it was the drapers' industrial capital along with the power to mobilize, militarily if necessary, a large workforce of small producers and wage workers that formed the basis of the guilds' political power. ${ }^{26}$

24. Dumolyn, "Guild Politics", with extensive references there.

25. Marc Boone, "Les métiers dans les villes flamandes au bas moyen âge (XIVe-XVIe siècles). Images normatives, réalités socio-politiques et économiques", in Pascale Lambrechts and JeanPierre Sosson (eds), Les métiers au Moyen Age. Aspects économiques et sociaux. Actes du Colloque international de Louvain-la-Neuve, 7-9 octobre 1993 (Louvain-la-Neuve, 1994), pp. I-2I; Catharina Lis and Hugo Soly (eds), Werelden van verschil. Ambachtsgilden in de Lage Landen (Brussels, 1997); Peter Stabel, "Guilds in Late Medieval Flanders: Myths and Realities of Guild Life in an Export-Oriented Environment”, Journal of Medieval History, 30:2 (2004), pp. I 87-2 I 2, and Maarten Prak et al. (eds), Craft Guilds in the Early Modern Low Countries: Work, Power and Representation (Aldershot, 2006).

26. Catharina Lis and Hugo Soly, "Export Industries, Craft Guilds and Capitalist Trajectories, I $3^{\text {th }}$ to I8th Centuries", in Prak et al., Craft Guilds in the Early Modern Low Countries, pp. 107-I $3^{2}$. 
The greater the concentration of corporately organized labour, the more skilled work became a central principle of urban society and culture. And the more the balance of power shifted towards the guilds, the further they developed their political practice and ideas within the urban political arena, with the result that a more self-conscious workers' identity focusing on quality and skilled work emerged during the fourteenth century. ${ }^{27}$ By the end of the fourteenth century, the urban artisans also seemed to have gained more cultural self-consciousness, as ever more literary works were produced within the sphere of corporate organizations. ${ }^{28}$ This "classic age" of the Netherlandish crafts ended in the mid-sixteenth century. Guilds continued to play major economic and social roles, but they had lost their military function, and their direct or indirect right to political participation was either ended or curtailed in most cities. ${ }^{29}$

\section{ANALYSING GUILD IDEOLOGY}

Anthonis's praise of manual work testifies to the fact that for the urban artisans of medieval Bruges, labour was a cornerstone of their community life, cultural experiences, practical ethics, and political visions, but his writings also contain several key elements of "craft guild ideology". The discursive world of Netherlandish artisans originated in and was reinforced by guild meetings, drafting of complaints, negotiations with authorities, collective action, and gatherings for military, charitable, and devotional purposes. Guild discourses and symbols became permanent, structural, and omnipresent features in urban society and culture. Within this social and symbolic context, I define "guild ideology" as a discourse representing the corporately organized artisans' perception of their position in the late medieval urban world, a space of speech acts and collective performances that simultaneously shaped and was shaped by practices of production, reproduction, power relations, and communal organization. And although I agree with Rosser that there existed a more general "medieval guild ideology" or "corporatist thought" inspired by standard Christian moral discourses, it must be stressed that the later

27. Peter Stabel, “The Move to Quality Cloth: Luxury Textiles, Labour Markets and Middle Class Identity in a Medieval Textile City. Mechelen in the Late Thirteenth and Early Fourteenth Centuries", in Bart Lambert and Katherine A. Wilson (eds), Europe's Rich Fabric: The Consumption, Commercialisation, and Production of Luxury Textiles in Italy, the Low Countries and Neighbouring Territories (Fourteenth-Sixteenth Centuries) (Aldershot, 2016), pp. I 59-179.

28. Dumolyn, "Het corporatieve element".

29. Catharina Lis and Hugo Soly, "Craft Guilds in Comparative Perspective: The Northern and Southern Netherlands. A Survey", in Prak et al., Craft Guilds in the Early Modern Low Countries, pp. I-2; Maarten Prak, "Corporate Politics in the Low Countries: Guilds as Institutions, I 4 th to I 8th Centuries", in Prak et al., Craft Guilds in the Early Modern Low Countries, p. 77. This same pattern also appeared in other European regions, such as northern Italy and the Rhineland, where guilds had secured political influence during the fourteenth century. 
medieval artisan ideology was specifically connected to the world of urban skilled work itself. This was a language of community, a paradigm constructed around keywords such as "unity", "brotherly love", "charity", "liberties", and "justice". While these ideological signifiers are familiar to specialists in medieval and early modern guilds and confraternities all over Europe, in the urbanized and industrialized Low Countries the practice and idea of labour itself, and notably of skilled and "honest" labour, added a specific dimension.

In order to demonstrate this, I must make use of a specific methodological approach that differs from earlier attempts to penetrate the essence of the "guild ethos" of the Middle Ages, and notably from that of Antony Black, who, as a historian of political ideas, chiefly relied on theological and legal treatises. The guild ethos he discerned was based on values such as friendship, mutual aid, and brotherhood, which occur in learned texts. But in contrast to the Italian cities where some jurists, theologians, and philosophers, such as Bartolo di Sassoferato, Remigio di Girolamo, and Marsilio di Padua, compared "high theory" to their own societies, no one north of the Alps wrote a coherent theory of corporatist urban politics before Johannes Althusius, an early seventeenth-century German clerk from Emden. ${ }^{30}$ Historians have attempted to discern medieval artisans' political views largely by examining "practical" documents, such as court records, guild by-laws, and urban chronicles. Guildsmen's petitions or charters referring to complaints that preceded them are particularly interesting as they show more ideological languages than statutes, which are usually technical and mostly limited to the organization of production and markets. ${ }^{31}$

There are remarkable discursive resemblances between Anthonis's literary efforts and a number of such archival texts, indicating the impact of the craft guild ideology, one centred on the value of work within the body politic. For instance, in I4 I 5 , Bruges's skippers' guild decided to erect an almshouse for its brothers and their families. The text displays exactly the same line of thought as the mason's critical poems: many guild members had engaged in "heavy labour" when they were young but were no longer fit and unable to "win their bread". For these brothers to go begging with their wives and families would be unjust, so the guild should secure their livelihood. ${ }^{32}$ In order to grasp the essence of the guild ideology of the Low

30. Antony Black, Guilds and Civil Society in European Political Thought from the Twelfth Century to the Present (London, 1984), pp. 29-30.

3 I. Compare with the far better documented eighteenth-century guilds studied by Kaplan Kaplan, "Idéologie, conflits et pratiques politiques", and idem, "Social Classification and Representation in the Corporate World" - or by Maarten Prak, "Individual, Corporation and Society: The Rhetoric of Dutch Guilds (I 8th Century)", in Marc Boone and Maarten Prak (eds), Statuts individuels, statuts corporatifs, statuts judicaires (Leuven, I996), p. 257.

32. Emiel Huys, Duizend jaar mutualiteit bij de Vlaamsche gilden, bijlagen (Kortrijk, I926), pp. $170-172$. 
Countries, my method juxtaposes these two types of source, which - as Kaplan has also argued - often explicitly or implicitly evoke the importance of work as something that provided artisans with a specific social position and hence with a necessity for solidarity among guildsmen.

In I 470, for instance, the guild of the "sworn corn measurers on water" in the flourishing metropolis of Antwerp argued that they should have their own mutual aid fund, as "most of them were humble fellows and had nothing else than what they could gain through their hard labour", and they often fell ill. But in the name of God and as brothers, they owed each other "compassion, brotherly affection and love". ${ }^{33}$ Aerbeyd, the "labour" paradigmatically connected to this brotherly love, was but one way to refer to work. The term neringhe can also be translated as "work", but often in the more economic sense of "trade" or "business". It derives from the verb neren or gheneren, which meant "to secure one's livelihood". Sometimes neringhe also served as a synonym for ambocht or ghilde, referring to the organized craft institution itself. ${ }^{34}$ Moreover, highly skilled artisan labour was also specifically denoted by the word conste, or "art". In an allegory from the Bruges Gruuthuse manuscript, a major collection of Middle Dutch poetry from c.I 400 , the paradigmatic relations between signifiers such as const ("skilled work"), cracht ("force", "energy"), aerbeit (sometimes formulated as zwaren aerbeyde or "heavy labour"), wercken ("to work"), wrochten ("to fabricate something"), and des aerbeits loon ("the wages of labour") or else den rechten loon der consten ("the right wages for skilled work") form a general metaphorical framework for human relations and love, another literary expression of the guild ideology of the furriers and other luxury-industry crafts and confraternities linked to this manuscript. ${ }^{35}$

\section{HONEST LABOUR AND A DECENT LIVELIHOOD}

As might be expected, basic economic issues were very present in the ideological value artisans attributed to both their labour and proper wages, whether daily or piece wages. Small producers who sold their goods directly also wanted fair prices to secure their livelihood, and there were some improvements. During the Late Middle Ages, artisans' diets generally became more varied, and more of them could afford meat and fish. The average urban artisan in the Low Countries probably spent about seventy

33. Ibid., appendices, pp. 4-5.

34. Middle Dutch dictionaries can be consulted at http://gtb.inl.nl.

35. Joris Reynaert, "Wat is conste? Het begrip 'kunst' en de artistieke context van het Gruuthusehandschrift”, in Jos Koldeweij, Inge Geysen, and Eva Tahon (eds), Liefde en devotie. Het Grunthusehandschrift. Kunst en cultuur omstreeks 1400 (Antwerp, 2013 ), pp. 2 I 5 -230; cf. Sewell, Work and Revolution in France, pp. 22-24. 
to eighty per cent of their budget on food and five to fifteen per cent on rent, while the remainder was used for heating, light, clothing, and utensils. Except for times of serious crisis and very high prices, many master guildsmen like Anthonis enjoyed a reasonable standard of living and consumed significant quantities of meat, especially during the mid-fifteenth century. However, journeymen often had a far more difficult time, especially when food prices rose; subcontracting masters were often no better off, and could experience rapid downward social mobility following a crisis. ${ }^{36}$

Indeed, in one of the plays by the early sixteenth-century fuller and dyer Cornelis Everaert, another Bruges rhetorician and social critic, the character Den Scaemele Aerbeyder ("Shabby Worker", a poor journeyman) is fired by his employer Menichte van Volke ("Multitude of People", a master artisan). Shabby Worker complains that wage labourers suffer the worst in a crisis as the guild masters pass the effects on to them. ${ }^{37}$ And in another of his pieces, the two main allegorical characters Groot Labuer ("Hard Labour") and Sober Wasdom ("Meagre Profit") represent a carpenter and a mercer respectively. They lament the hard times, the small profits, and the impossibility of making a living. ${ }^{38}$ Everaert also created Scamel Ghemeente ("Shabby Commoner"), representing the impoverished popular classes, who bemoans the loss of his trade and that he can no longer eat capons or drink beer and wine. He lists the lower prices of the year before, when there was still profit, and money earned through hard labour still provided a decent standard of living. ${ }^{39}$

Again, such literary works by guildsmen resonate with the petitions of other artisans, often fullers, who worked in great numbers in the textile industry and complained of low wages. In I 355 , for instance, the fullers of Dendermonde said that they had such "bad and small wages" that they would not provide for their livelihood during the current "expensive times" ${ }^{40}$ In I 367 , they again complained about the dire times and the low

36. Thoen and Soens, "Vegetarians".

37. J. Müller, "Cornelis Everaerts spelen als spiegel van de maatschappelijke toestanden zijns tijds", Verslagen en Mededeelingen der Koninklijke Vlaamsche Academie voor Taal- en Letterkunde (1907), pp. 442-448; Wim Hüsken (ed.), De spelen van Cornelis Everaert. Opnieuw uitgegeven, van inleiding, annotaties en woordverklaringen voorzien, 2 vols (Hilversum, 2005), I, pp. 494-495; Jan Dumolyn and Jelle Haemers, "Let Each Man Carry on with his Trade and Remain Silent: Middle-Class Ideology in the Urban Literature of the Late Medieval Low Countries", Cultural and Social History, 10:2 (2013), pp. 169-189.

38. Hüsken, De spelen, I, pp. 527-560.

39. Ibid., I, p. 320.

40. Georges Espinas and Henri Pirenne (eds), Recueil de documents relatifs à l'histoire de l'industrie drapière en Flandre, 3 vols (Brussels, I 906), III, p. 378; for the context see H. Van Werveke, "De economische en sociale gevolgen van de muntpolitiek der graven van Vlaanderen (1337-1433)”, Annales de la Société d'Emulation de Bruges, 74 (1931), pp. 6-8. 
wages that prevented them from "winning their bread". ${ }^{\text {I }}$ Similarly, the shearers of Oudenaarde demanded "reasonable pay" in times of monetary devaluation. ${ }^{42}$ But beyond mere self-interest, artisans believed that the welfare of their town ultimately depended upon their work. The value accorded to skilled labour organized by guild norms supported this typical "middle-class" socio-political perspective, again seen in both literary texts and guild charters. ${ }^{43}$ Additionally, social critiques that consciously articulated artisans' views by criticizing both higher and lower social groups must also have been widely dispersed orally in the Low Countries. One popular song, quoted by Everaert, was a wordplay on the game of backgammon: "Two and One do not have, Six and Five do not give, but Four and Three must give, for Six and Five to live." 44 "Two and One" were the poor, "Four and Three" represented the middle classes, and "Six and Five" were the wealthy elites. The message was clear: craftsmanship produced wealth for all.

Moreover, as Anthonis also stressed, labour had to be honest because it has such moral communal importance. Guild statutes universally condemned cheating and usury, thereby supporting quality control. ${ }^{45}$ A I 33 I Mechelen textile by-law prohibited "falseness in working with wool", and ordered artisans to observe standards of brotherly respect. ${ }^{46}$ A I 302 privilege of the blacksmiths of 's-Hertogenbosch in Brabant included the usual regulations on raw materials, membership fees, apprentice recruitment, labour relations, attendance at guild meetings, and religious and military obligations. However, it also stipulated that if someone called his guild brother a liar and was proven wrong by witnesses, the offender had to pay a heavy fine. ${ }^{47}$

Likewise, for the guildsmen, maintaining quality standards was a legal and moral expression of the importance of skill, trust, and reputation in labour. This was not only, as New Institutional Economics would have it, about reducing "search and information costs" for potential buyers by ensuring that they were purchasing from a trustworthy source - even

4I. Espinas and Pirenne, Recueil, III, p. 384.

42. Ibid., I, pp. 297-298.

43. Dumolyn and Haemers, "Let Each Man Carry on with his Trade".

44. "Dues aes en heeft niet / Six cinq en gheeft niet / Maer quater dry die moeten gheven / Daer six en cinq by moeten leven"; Jacob W. Muller and Lodewijk Scharpé (eds), Spelen van Cornelis Everaert (Leiden, I920), p. 577.

45. James R. Farr, "On the Shop Floor: Guilds, Artisans, and the European Market Economy, I350-1750", The Journal of Early Modern History: Contacts, Contrasts and Comparisons, I:I (1997), pp. 24-54.

46. Henri Joosen, "Recueil de documents relatifs à l'histoire de l'industrie drapièr a Malines (des origines à I 384)", Bulletin de la Commission Royale d'Histoire, 99 (1935), p. 498.

47. Nicolaas H.L. van den Heuvel, De ambachtsgilden van 's-Hertogenbosch vóór 1629. Rechtsbronnen van bet bedrïfsleven en het gildewezen (Utrecht, 1946), p. 6. 
though artisans would likely have understood such basic economic mechanisms. No, the central ideological concern of such guild records and literary texts was the ability of a family man to make a decent livelihood. ${ }^{48}$ While Adam Smith dismissed the guilds' regulations as a "cartel function" and "rent-seeking", such rules were motivated by the artisans' desire for social and economic independence. Fundamentally, setting the price of honest labour was about the masculine capacity of a paterfamilias to maintain himself and his family and uphold his place in society. ${ }^{49}$ In I 374 , for instance, the "modest people" of the Ghent buutslaghers ("tenterers"), who worked in the finishing stage of cloth production, asked for higher wages "to maintain themselves, their wives, and their children, having the urgent necessity to secure their estate", and they received a twenty-five per cent pay raise..$^{\circ}$

Guild regulations also reflected a moral judgement privileging the rights of the corporate collective of workers over those of the individual and an attempt to maintain at least some equality within the urban world of labour. Weavers' statutes, for example, limited the number of journeymen and apprentices each master could have and the number of looms he could own to prevent excessive capital accumulation. An aversion to rapid self-enrichment at the expense of poorer colleagues is typical of artisans all over medieval and early modern Europe. ${ }^{\text {II }}$ But expressing this social and moral criticism in literature often also meant taking a political stand, and guild authors in the Netherlands appear sometimes emboldened by their powerful position. Some of Everaert's plays questioning the government's economic and military policies were effectively banned by the authorities. $^{52}$

During hard times in the province of Holland in 1565 , the Haarlem playwright Lauris Jansz wrote several social critiques that asserted the moral and political middle-class consciousness of guildsmen. Characters in his plays such as "Never Enough" (Nimmermeer Genouch) and "Insatiable Desire” (Onversaedge Begeert) represented greedy merchants. Yet while Jansz often attacked grain speculators and corrupt officials, he did not advocate affluence for the working classes, but rather sought unity and peace to ensure each his daily bread through hard and honest work,

48. For instance for Oudenaarde, in Espinas and Pirenne, Recueil, I, pp. 282-283, 285 .

49. Prak, "Individual, Corporation and Society", pp. 260-262. See also James R. Farr, The Work of France: Labor and Culture in Early Modern Times, I350-I800 (Plymouth, 2008), pp. 83-87, and idem, "Cultural Analysis and Early Modern Artisans", in Geoffrey Crossick (ed.), The Artisan and the European Town, I500-1900 (Aldershot, 1997), p. 57.

50. Espinas and Pirenne, Recueil, II, p. 539.

51. Lis and Soly, Worthy Efforts, p. 348.

52. Wim Hüsken, "Cornelis Everaert and the Community of Late Medieval Bruges", in Alan Hindley (ed.), Drama and Community: People and Plays in Medieval Europe (Turnhout, 1999), pp. IIO-I 25 . 
frugality, simplicity, and sharing the remainder. ${ }^{53}$ Thus, around the value of their work, artisans deployed a language of intersecting notions: the worth of skill and reputation, brotherly respect, honesty, trustworthiness, and quality control, supported by adequate wages and prices. In petitions, regulations, and literary works, artisans condemned the accumulation of excess wealth and argued that communal welfare primarily depended upon honest labour.

\section{A POLITICAL LANGUAGE OF JUSTICE AND REBELLION}

Conscious of their strength, the Low Countries guilds also created a mobilizing ideology, which was frequently employed during social and political conflict. In addition to deploying economic power, strike action also carried an ethical and political undertone. A strike would usually start with a rallying cry or roup. In 1377 , for instance, Hannin de Werd from Ypres was beheaded because he had called on his fellow citizens "not to go to work". And while the strike failed and people returned to work, "they retained their bad opinions". 54 The strikers had witheld their crucial productive labour from the community by methods such as ledichganck ("going idle", i.e. striking) and untganck ("going out", i.e. leaving the city), until justice was restored. 55 These rallying cries for collective action often go to the heart of the artisans' political ideology. ${ }^{56}$ In I 432, the weavers of Ghent launched a political strike against monetary reforms that harmed their living standards, and other artisans swiftly joined. "All together, all together", they cried in solidarity, "we are all weavers now!" 57 As in the theoretical treatises studied by Black, unity and brotherly love were the keywords in guild politics, but their use in this context was clearly founded upon concrete socioeconomic solidarity.

Yet, while the guilds as a political movement were eager to maintain their power, they also felt responsible for their community as a whole. For them, the difference between the virtuous rule of body and soul that Anthonis promoted and good governance was only cosmological in scale. Guild leaders assuming political positions swore solemn oaths to maintain unity as

53. Willem M.H. Hummelen, De sinnekens in het rederijkersdrama (Groningen, I958), p. 278.

54. "dat zy niet te werke gaen zouden" and "in quader meeninghe"; Jean-Jacques Lambin (ed.), Merkwaerdige gebeurtenissen, vooral in Vlaenderen en Brabant, en ook in de aengrenzende landstreken. Van 1377 tot 1443 (Ypres, I835), pp. I-2.

55. Jan Dumolyn, "The Vengeance of the Commune: Sign Systems of Popular Politics in Medieval Bruges”, in Hipólito Rafael Olíva Herrer et al. (eds), La comunidad medieval como esfera publica (Seville, 20I4), pp. 25 I-289.

56. Jan Dumolyn and Jelle Haemers, "A Bad Chicken was Brooding: Subversive Speech in Late Medieval Flanders”, Past and Present, 2 I 4:I (20I 2), pp. 45-86.

57. “Alle eens, alle eens!", Victor Fris, "De onlusten te Gent in I432-1435”, Bulletijn der Maatschappij van Geschied-en Oudheidkunde te Gent, 8 (1900), p. I67. 
the city's wardens. Artisan rebels in 1436 Bruges and in I477 Antwerp promised to "nourish" and "eternally maintain brotherly love and unity in this city", "to live and die with each other like brothers", and to lend each other "support" and "loyalty". $5^{8}$ Other keywords in the artisans" discourse of political action were "liberties" or "privileges" (vrybede), and "customs" (costumen ende usagen) - the rights they had obtained through guild struggle - and they blamed their merchant-class opponents for "bad governance". 59

When tensions increased and the fruits of their labour were increasingly threatened, artisans might employ more radical language. During their revolt against Charles V in I $53^{8}$, an official report recorded that the Ghent craft guilds were repairing the artillery and other weapons they kept in their guild houses, and they assembled "as if they were waging an open war and wanted to fight the whole world; so stubborn and presumptuous were they". Young guildsmen, "who always talk more lightly and boldly than the elderly", confidently claimed that they had good reasons for everything, though the author found these "quite small". The artisans said their actions followed the course of justice, and they would bring order and good government to Ghent and Flanders as a whole so that "industry and profit" would improve for everyone. They also wanted to lower the prices of all goods. ${ }^{60}$ It was only fair that people be able to live off the proceeds of their honest work, and this was precisely what "liberty" meant to them. ${ }^{61}$ Upon achieving full membership, guild artisans were "freed" (bevryet) and the medieval expression of "free labour" means exactly that: economically independent labour based on skilled craftsmanship. ${ }^{62}$ Artisans' political language was therefore deeply threatening to commercial elites in times of economic hardship, as their concept of good governance included maintaining or demanding higher wages and lower prices.

58. "omme te voedene broederlijke minne en eendrachtichede binnen deser stede"; "teeuwigen dagen bruederlike mynne te onderhoudene ende te doene"; "deen metten anderen broederlike te levene ende te stervene”; Jan Dumolyn, “'Rebelheden ende vergaderinghen'. Twee Brugse documenten uit de grote opstand van $\mathrm{I}_{436-\mathrm{I}} 438$ ", Handelingen van de Koninklijke Commissie voor Geschiedenis, I62 (1996), pp. 3 I 8-3 19 ; Pierre Génard (ed.), De gebroeders Van der Voort en de volksopstand van 1477-I478. Verbalen en ambtelijke stukken (Antwerp, I879), p. 53.

59. Lambin, Merkwaerdige gebeurtenissen, pp. $3^{-5}$.

60. "comme se ilz eussent eu guerre ouverte, et voullu combatre tout le monde, tant estoient hardis et présomptueux"; "qui sont tousjours plus légiers et hardis de parler que les anchiens"; “toutes choses seroient a meilleur et plus raisonnables pris qu'elles n'estoient, et que par ainsy le people viveroit plus a son ayse et en beaucoup plus grande liberté qu'ilz n'avoient fait le passé”: Louis Prosper Gachard (ed.), Relation des troubles de Gand sous Charles-Quint par un anonyme (Brussels, I 846), pp. 8-io.

6r. Compare with Samuel K. Cohn, Lust for Liberty: The Politics of Social Revolt in Medieval Europe, I200-I 425 (Cambridge, 2006), pp. 236-242.

62. Lis and Soly, Worthy Efforts, p. 345. 
Although the concept of justitia was common in medieval legal and theological texts in connection with others such as aequitas, pax, bonum commune, and utilitas publica, in the artisans' concrete view of the "political economy" justice included economic justice. The rebels expressed their economic, monetary, and fiscal demands within a discourse of "the common weal of the city". Medieval urban governments commonly propagated the same general ideology, but it could be turned against them. Regarding taxes, for example, rebels usually denounced the unjust division and improper use of monies by the city oligarchs rather than the taxes themselves. ${ }^{63}$ However, radicals, usually the "angry young men" of the guilds, would sometimes go further and demand an end to all taxes. During a 1467 revolt in Mechelen, rebels demanded that all taxes be abolished, that the authorities disclose how revenues were spent, and that "a new world" be created - if we may believe the Burgundian court chronicler with Flemish origins Georges Chastellain. ${ }^{64}$ But certainly, hurling charges of bad governance and demanding justice, artisan radicals could often turn the common ideology of urban government against the authorities. However, sometimes, during urban revolts in Flanders, guild leaders did not allow the poorest layers of the artisan class and the unskilled wage workers to speak out. ${ }^{65}$

\section{LANGUAGES OF CLASS AND HIERARCHY}

Indeed, despite the radical potential of artisan ideology formulated around the central value of maintaining a decent livelihood through honest and skilled labour, the political language of the craft guilds supported hierarchical order as well as equality. The revolutionary view of a world turned upside down was very rare among more prosperous Netherlandish artisans, even though guildsmen collectively organized strikes and demonstrations, temporarily withholding their goods and services from the community as a whole when they deemed it necessary. ${ }^{66}$ Too much emphasis on the subversive side of craft politics and ideology obscures the fact that the guilds operated as fully recognized and legitimate parts of the urban body politic and urban government institutions in their own right in most of the major

63. Jan Dumolyn and Kristof Papin, "Y avait-il des 'révoltes fiscales' dans les villes médiévales des Pays-Bas méridionaux? L'exemple de Saint-Omer en I467”, Revue du Nord, 397 (2012), pp. $827-870$.

64. "seroient mises jus maletostes et impositions, et sçauroient que tels et tels deniers estoient devenus, qui si longuement avoient esté reçus au grief du peuple, et feroient, par le Saint Dieu! Un monde nouvel, ce disoient aussi bien à leur tour comme avoient fait autres": Joseph Kervyn de Lettenhove (ed.), Oewvres de Georges Chastellain (Brussels, i864), V, p. 308.

65. Jan Dumolyn, "Criers and Shouters: The Discourse on Radical Urban Rebels in Late Medieval Flanders”, Journal of Social History, 42:I (2008), pp. I I I-I35.

66. Dumolyn and Haemers, "Patterns of Urban Rebellion in Medieval Flanders", pp. 369-393. 
industrial towns of the Low Countries. They not only played a major role in regulating labour and markets, they also assumed military and legal functions delegated to them by the city authorities. Even in towns that did not permit their direct representation in government, guilds usually had the right to deliberate and petition rulers in order to safeguard their economic interests. ${ }^{67}$

However, it must also be emphasized that artisan labour cannot be directly associated with a single social class, so that, as Kaplan also observed, even if a guild ideology encompassed shared values, there were inevitable contradictions between theory and practice. In fact, in early modern guilds, the gap between masters and journeymen or between the poorer and richer masters had usually greatly widened. ${ }^{68}$ The same was already often true in the later medieval Low Countries, where artisans, particularly in the large, industrial centres, belonged to different "classes" in the strictly Marxist sense of the word. A retailer had interests distinct from those of an export textile worker; a luxury craft artisan possessed far more capital than a minor shoemaker. In small, wealthy crafts, such as those in the luxury trade, a prosperous class of masters divided power somewhat equally among themselves, while in the large textile guilds socioeconomic polarization between the richer and poorer artisans was far greater. Many masters produced to order while employing journeymen and subcontracting masters. Local market retailers were also usually less politically militant than weavers.

In fact, the guild masters never took the problem of structural misery among their own badly paid journeymen seriously, let alone that among the unskilled and non-corporately organized workforce. ${ }^{69}$ This matter was not really discussed in the official guild records. However, the struggles between fullers and master weavers - the former were dependent on the latter for wages and employment - did leave their historical traces, as at times they caused violent confrontations in Ghent and other towns. ${ }^{70}$ Defending the interests of the most impoverished and downtrodden layers of urban society was never a priority for the craft guilds; they had little time for their poorest "in-group" and certainly none for those of the "out-groups". Wider solidarity could develop among the working masses and the poor when excessive taxes sparked a revolt, but, on every occasion,

67. See Dumolyn, "Guild Politics".

68. Steven L. Kaplan, "The Character and Implications of Strife among the Masters inside the Guilds of Eighteenth-Century Paris", Journal of Social History, I9:4 (I986), pp. 63 I-647.

69. Jean-Pierre Sosson, "Corporation et paupérisme aux XIVe et XVe siècles. Le salariat du bâtiment en Flandre et en Brabant, et notamment à Bruges”, Tijdschrift voor Geschiedenis, 92 (1979), pp. 557-575.

70. Marc Boone and Hanno Brand, "Vollersoproeren en collectieve actie in Gent en Leiden in de I4de-I sde eeuw", Tijdschrift voor Sociale Geschiedenis, I9:2 (1993), pp. I68-192; Boone, "Les métiers dans les villes flamandes". 


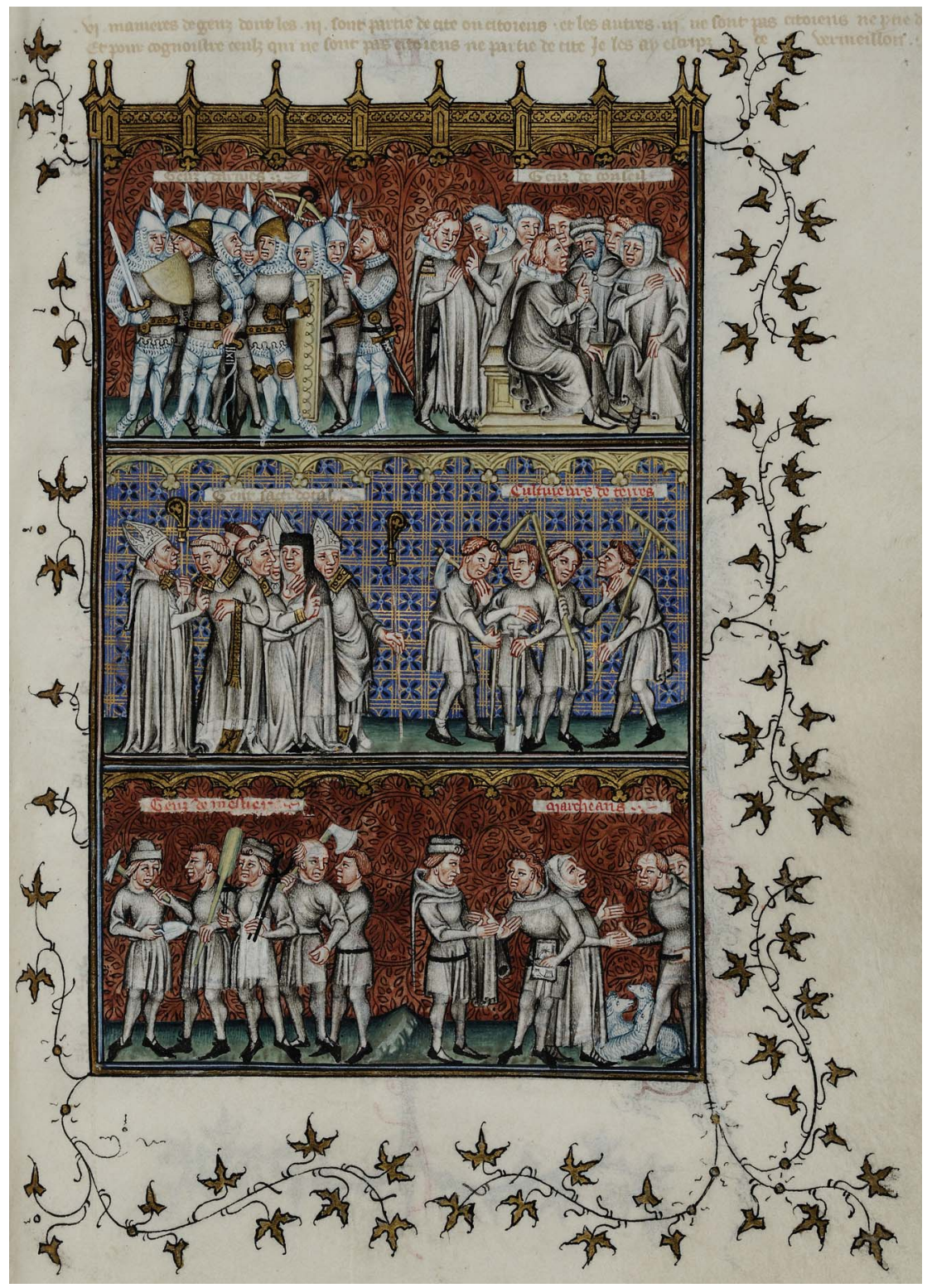

Figure I. Soldiers, counsellors, clergymen, labourers, craftsmen, merchants, I4th c. (second half) (1376).

Royal Library of Belgium; KBR, ms. I I 20I-02, fol. 263. Used with permission. 
the middle classes and guild elites would direct these revolts towards their own specific interests. ${ }^{71}$

Moreover, during urban conflicts, the wealthiest members or masters of powerful, monopolistic craft guilds, such as food suppliers, normally sided with the commercial elites rather than with the mass of artisan workers. Moreover, the corporate system not only contained internal class and status differences, and hierarchies, it also excluded "outsiders": foreigners and rural artisans, members of rival crafts, unskilled workers, and women, although the latter, principally the widows of deceased masters, could belong to some guilds. ${ }^{72}$ Nevertheless, in the constantly shifting urban social environment, corporatist forms of organization did create a degree of mutual confidence, aid, credit relations, and risk-sharing that could cross internal hierarchies and class lines. ${ }^{73}$ The shared value of their work and the political struggle to ensure its economic fruits often united all artisans alike. In the end, despite often major differences in material resources and economic standing, their shared experiences and political interests enabled the Low Countries guildsmen to develop and articulate certain common values. As was the case in eighteenth-century Paris, even if the corporate discourse of internal solidarity might also have served as a tool of social control for the masters and leaders of the guilds, ${ }^{74}$ the similar socioprofessional trajectories, the shared values, and most of all the common political interests of the Low Countries artisans were fundamental to the genesis and effects of their guild ideology.

And yet, political critique was also surely an internal feature of guilds. The late fourteenth-century Holland writer Willem van Hildegaersberch wrote a poem titled "On Guilds" (Van Ghilden), presumably for an unidentified corporate organization. Guilds, he said, were created to promote brotherly love and unity; they needed to elect leaders to maintain this, and all conflicts should be settled in their general assembly. ${ }^{75}$ The text was probably performed during a conflict over leadership or an election, and again, craft guild ideology combined both equality and hierarchy. Richer masters, who frequently formed an oligarchy within the corporation,

7r. Dumolyn, “Criers”.

72. Soly, "The Political Economy of European Craft Guilds"; Franco Franceschi, "L'organizzazione corporativa delle grandi manifatture tessili nell'Europa occidentale. Spunti comparativi", in Tra economia e politica: le corporazioni nell'Europa medievale (Pistoia, 2007), pp. 333-357. For the organization of female labour in Flanders, see Martha C. Howell, Women, Production, and Patriarchy in Late Medieval Cities (Chicago, IL, I986), and Shennan Hutton, Women and Economic Activities in Late Medieval Ghent (New York, 20 I I).

73. Gervase Rosser, "Solidarités et changement social. Les fraternités urbaines anglaises à la fin du Moyen Age”, Annales. Économies. Sociétés. Civilisations, 48:5 (1993), pp. I I 30, I 142.

74. Kaplan, "The Character and Implications of Strife".

75. Willem Bisschop and Eelco Verwijs (eds), Willem van Hildegaersberch: Gedichten (The Hague, I870), pp. I I7-I I 9 . 
deployed a discourse of solidarity to suppress internal discord, reject the demands of journeymen and apprentices for higher wages and improved labour relations, and protect the interests of their guild from the claims of rival corporations.

Sources sometimes preserve ideological utterances by poor journeymen such as Everaert's "Shabby Worker" or those of young apprentices. Age formed a social barrier just as gender did, and mostly prevented these "subalterns" within the guilds from speaking. While women and young boys and girls were economically vital for artisan production in their households, guilds remained fundamentally adult, homosocial cultural environments with patriarchal values and self-representations. A guild master was usually a married householder who not only dominated his dependants, but also his apprentices. Boys started learning their craft's skills between the ages of eight and fifteen on the shop floor while living in the household of their masters, who socialized them into urban society. As unmarried servants, they aspired to eventually reach the master's position, but until then were subject to the latter's quasi-parental authority. ${ }^{76}$

For the medieval artisan, the possibility of socioeconomic mobility depended not only on the general political, industrial, and commercial climate, but on his own skills as well. "It's a bad thing to dig without a shovel [...]. It's a bad thing to forge iron that is not glowing [...]. It's a bad thing to work without any hope of success", Anthonis wrote, but he considered it equally wrong "to not know how to do something without trying to learn it". ${ }^{77}$ An artisan should indeed be enabled by those in power - the city authorities, the merchant class, or his craft's leadership - to secure his livelihood through hard work, but he was also responsible for improving his skills and producing quality goods. Again, the Bruges mason seems to address the apprentices he had lectured on obedience. Apprenticeship was a fundamental formative period for both obtaining the necessary competences and being socially disciplined, and so was the following position of a journeyman, dependent on wage labour, hoping to become a master craftsman. For numerous journeymen this status was not a mere phase in their life cycle, and they remained perpetual wage workers. Some were in a liminal position, labouring for their masters and hoping to eventually start a workshop of their own. Yet others became masters but remained dependent

76. P.J.P. Goldberg, “Masters and Men in Later Medieval England”, in Dawn M. Hadley (ed.), Masculinity in Medieval Europe (London and New York, 1999), pp. 56-70; Maarten Prak, "Moral Order in the World of Work: Social Control and the Guilds in Europe", in Herman Roodenburg and Pieter Spierenburg (eds), Social Control in Europe, vol. I: I 500-I 800 (Columbus, OH, 2004), pp. 176-199. On apprentices, see Bert De Munck, "From Brotherhood Community to Civil Society? Apprentices between Guild, Household and the Freedom of Contract in Early Modern Antwerp", Social History, 3 5: ( 2010), pp. I-20.

77. Mak, De gedichten, p. 265. 
on some of their richer guild brothers or never acquired the latter's economic or social position. ${ }^{78}$

Yet, it is important to note that in the medieval Low Countries, journeymen were considered full members of the guild and were almost never organized in separate compagnonnages or Gesellenverbände as in later medieval Germany or early modern France, even though they usually had no right to vote or to become dean or wardens. The exceptions to this were some textile crafts in larger, early fourteenth-century towns such as Ghent, Bruges, and Saint-Omer, indicating that during the revolutionary times following I 302 they were certainly acknowledged as a social force and participated in internal guild politics. However, during the fifteenth century, their social and political position seems to have deteriorated in comparison to the elite masters, and journeymen sometimes created their own separate religious fraternities, ostensibly with merely devotional and charitable functions but probably serving as socioeconomic interest groups as well. ${ }^{79}$ Nevertheless, in the Low Countries open conflicts between masters and journeymen are almost entirely absent from later medieval sources, so it again appears that, in the end, their common social and political position within the city had a stronger ideological impact than any divisions among them.

When tensions did arise, the guild documents used a language of brotherly love to assuage them. In I473, the leaders of the linen weavers' guild in 's-Hertogenbosch issued a charter stating that "all the good journeymen together have unanimously agreed" and "amiably decided" to prevent conflicts and violations of the statutes. Although there had clearly been some labour conflict, the issue at stake was not explicitly stated. However, while the apprentices involved were forced to comply in some fashion, the leaders also stipulated that a master who became so drunk that he had to vomit, either at work or an inn, had to pay a hefty fine of two pounds, to be put towards services in honour of the guild's patron, St Severus. ${ }^{\circ \circ}$ Whether the problem of embarrassing drunkenness was directly related to the dispute is unknown, but this text clearly attempted to restore internal

\footnotetext{
78. Johan Dambruyne, "Journeymen, Social Rise and the Urban Labour Market in the Southern Netherlands during the Transformation from the Middle Ages to the Early Modern Period", in Natasja Peeters (ed.), Invisible Hands? The Role and Status of the Painter's Journeyman in the Low Countries, c.1450-C.1650 (Leuven, 2007), pp. I05-132; Catharina Lis and Hugo Soly, “'An Irresistible Phalanx': Journeymen Associations in Western Europe, I300-1 800", in Catharina Lis, Jan Lucassen, and Hugo Soly (eds), Before the Unions: Wage Earners and Collective Action in Europe, I300-I 850 (Cambridge, I994), pp. 3 I-34.

79. Hans Van Werveke, De medezeggenschap van de knapen (gezellen) in de middeleeuwsche ambachten (Antwerp, 1943), pp. 8-16.

8०. "alle die goey cnapen gemeynlic sijn eendrechtelic overcomen"; "mynlic overdragen": Van den Heuvel, De ambachtsgilden, I, pp. 259-26I.
} 
harmony by penalizing both parties and promoting brotherly love in the workplace under the patron saint's supervision.

However, even though the dominant language in craft guild documents dealing with conflict attempted to harmonize such tensions with the typical rhetoric of unity and brotherly love, and guilds politically acted as one, the sources did sometimes implicitly or openly acknowledge that there were divisions in wealth, status, and power within the ranks. The Liège brewers, for instance, amended their statutes in 15 I 8 , in order "to have rule of law and good governance within their said craft regarding brewing and other matters, as well for the rich, as the middle ones, and the poor". Their objective was that "the middle ones and the poor would not be too oppressed by the rich, and everyone would know how to behave". A production quota was imposed on large brewers, and masters' sons no longer had to pay an entrance fee, so that the fruits of honest labour would be more equally divided among all. ${ }^{81}$ Even though the value of labour that guild artisans ideologically shared certainly did not empower all of them to the same degree, work was to be performed with brotherly affection and without the conflicts that caused serious social division - a fundamental difference between medieval guild discourse and modern discourses of class, such as in socialism.

\section{LANGUAGES OF BROTHERLY LOVE AND CHARITY}

Finally, it must be noted that our emphasis on the socioeconomic and political conditions that brought about the genesis of a strong craft guild ideology in the later medieval Low Countries does not imply that the religious status of work was not another crucial dimension to the perception of meaning in labour. Again, the morality of hard work and thrift is present in the literary sources of the urban world just as it was in guild documents. Honest and hard work was already praised in the work of fourteenthcentury moralists such as the Antwerp scribe Jan van Boendale, and in popular didactic texts such as the Dietse Catoen and Die Dietsche Doctrinael. These texts disseminated Christian virtues to a lay audience by making use of everyday situations. In his Jans Teesteye ("John's Testimony"), Van Boendale addresses the fullers, weavers, mercers, shoemakers, tailors, skippers, "and all of you who perform labour". On earth, workers are among the lesser people, and must work hard to earn their daily bread. But "yonder" (ghinder), in Paradise, "you will be among the upper", higher ranked than the clerics who despise and

8I. "pour avoir ordre, regle et bon police en leur dit bon mestier concernant leur bressin et autres leus affairez, tant pour les riches, moyens et poeuvres"; "par la puissance des riches, les moyens et poevres ne soyent trop oppressés et que chascun sache comment se conduire": René Van Santbergen, Règlements et privilèges des XXXII métiers de la cité de Liège. Fascicule V. Les boulangers (Liège, 1953), pp. 34-45. 
oppress you. ${ }^{82}$ This clearly echoes Matthew I9:30 "[...] many who are last will be first", and such ideas might have been quite widespread.

Although the subject of the religious value of labour in the urban world of the later Middle Ages certainly requires further study, there is no doubt about its fundamental importance within Netherlandish guild languages. As with other types of medieval corporatist discourses, artisan ideology was deeply rooted in the more generally shared Christian principle of caritas, love for each other stemming from the love of God, and, as we have already seen, this principle was specifically expressed by brotherly affection within guilds. As Anthonis's writings demonstrate all too well, medieval artisan languages could not transcend religious discourse because it was the allencompassing framework that explained the world. It made no difference whether the specific interaction was what we now call "economic", "social", or "political". ${ }^{8}$ The early Christian writers, such as the Apologists and especially the Church Fathers, had already forged the paradigmatic associations among caritas, amor, frater, unitas, corpus, pax, concordia, and the related terms ubiquitous in guild ideology. ${ }^{8}$ Their language marked the social and political discourse of the medieval period. The members of the mystical body of the Church were all united in fraternity, albeit guided by its head. The ideal of fraternal love was imposed as a guiding principle in all medieval communities in close connection with the discourse on charity, the seven works of corporal mercy, and the ideal of personal morality. ${ }^{85}$ Yet, while clerics and merchants also spoke in these terms, for workers organized in craft guilds their labour was again at the core of their brotherly charity.

Even after they developed into guilds with primarily economic and military functions, crafts still retained fundamental aspects of nonprofessional brotherhoods in their religious devotions and charitable activities. The 's-Hertogenbosch linen weavers, for instance, promoted brotherly love under their patron saint. As the guild's "lord", the saint protected them from adversity; his intervention was essential to the collective identity and status of the guildsmen. ${ }^{86}$ Artists also often depicted

82. Ferdinand Snellaert (ed.), Nederlandsche gedichten uit de veertiende eeuw van Jan Boendale, Hein van Aken en anderen, naar het Oxfordsch handschrift (Brussels, 1869), pp. 214, 255; Frits van Oostrom, Wereld in woorden. Geschiedenis van de Nederlandse literatuur 1300-1400 (Amsterdam, 2013), pp. I 21, I39.

83. Miri Rubin, "Small Groups: Identity and Solidarity in the Late Middle Ages", in Jennifer Kermode (ed.), Enterprise and Individuals in Fifteenth-Century England (Aberdeen, 1991), p. I36. 84. Hélène Pétré, Caritas. Étude sur le vocabulaire latin de la charité chrétienne (Leuven, 1948). 8 5. Cathérine Vincent, Les confréries médiévales dans le Royaume de France, XIIIe-XVe siècle (Paris, I994), pp. 67-84; Rosser, The Art of Solidarity, pp. 89-I I 8.

86. Alfons K.L. Thijs, "Religieuze rituelen in het emancipatieproces van Vlaamse en Brabantse handwerksgezellen (zestiende-negentiende eeuw)", in Catharina Lis and Hugo Soly (eds), Werken volgens de regels. Ambachten in Brabant en Vlaanderen I 500-I 800 (Brussels, I994), pp. 239-240. 
saints with attributive tools connected to a particular guild, such as St Aubert baking bread, or St Luke painting the Virgin. Christ's tools have also sometimes been explained as the symbols of honest work. Skilled labour was thus sanctified using an existing Christian language. ${ }^{87}$ Moreover, as in various other types of medieval community, the sacraments, especially the mass, were probably the principal occasions for creating a social unity that transgressed differences.

However, not all members participated voluntarily. The Leuven brewers had to be forced by their guild wardens to attend Sunday mass at their St Arnold's altar. ${ }^{88}$ The same issue arose with liturgies, which also bound the living and deceased members of a guild together and symbolized their mutual ties. ${ }^{89}$ Leuven guildsmen were supposed to attend the funeral masses for their deceased brothers, but the regulations explicitly included the phrases "at the right hour" and "until the end", which clearly suggests disciplinary problems. Nevertheless, unity was strongly promoted: members were expected to visit the deceased's family, and guilds frequently had their own mortcloths for brothers' funerals. ${ }^{90}$ Selfish interests may have sometimes prevailed over comradely feelings and religious duty, but time was often short and work awaited.

Even so, Low Countries craft guilds created far stronger devotional and social ties for their members in comparison with religious confraternities that often met only once a year, on their patron saint's day. Members had much more interaction and face-to-face contact with each other. Not only were they bound by their shared skills and collective devotion, they were also involved in professional, commercial, and credit relationships. Retailers often shared market spaces, artisans in various sectors collaborated in producing commodities, and sometimes they also lived in the same neighbourhood. Additionally, together with the church bells, the work bells (werck clocken or clockes des ouvriers) structured the daily rhythm of almost the entire workforce. Especially in the textile industry, labour time was closely regulated and supervised by the crafts in cooperation with the city government, and this organization of daily life as defined by organized labour gradually became even more decisive than the liturgical calendar. ${ }^{\text {I }}$

87. Lis and Soly, Worthy Efforts, 346; Kellie Robertson, The Labourer's Two Bodies: Literary and Legal Productions in Britain, 1350-1500 (New York, 2006), pp. 4-6.

88. Jan Verhavert, Het ambachtswezen te Leuven (Leuven, 1940), p. 56.

89. Rubin, "Small Groups”, pp. I $35-138$.

90. "ter gepasten uren"; "tot den eynde”: Verhavert, Ambachtswezen, pp. 57-58, citing examples from Leuven, Ghent, Aalst, Namur, Lier, and Antwerp.

91. Peter Stabel, "Labour Time, Guild Time? Working Hours in the Cloth Industry of Medieval Flanders and Artois (Thirteenth-Fourteenth Centuries)", Tijdschrift voor Sociale en Economische Geschiedenis, I I:4 (2014), pp. 27-53. 
Guild meetings also contributed to constructing group sentiment by inducting new members, electing leaders, and reporting on finances and important issues. Meetings and feast days were occasions for banquets, literary performances of mystery plays or dramas, and reciting worldly texts. It was also on such occasions that artisan rhetoricians such as the mason Anthonis de Roovere and the fuller Cornelis Everaert would speak, formulating guild ideology more clearly than their less lettered brothers, albeit using rhetorical forms intertwined with religious considerations, but nevertheless still quite recognizable. Guilds were also central to the development of urban feast culture in general, and it was their identity as a collective of workers from a common trade that formed the basic unit for such revelry. ${ }^{92}$

Craft guilds thus functioned as artisans' primary models of solidarity, assuring basic personal security, mutual aid, and trust, reinforced by regular rituals and an ideological language of cohesion. While the older historiography emphasized these "social aspects" of guilds, they have received less scrutiny in recent years, even though Rosser reiterated that craft guilds also defended the material interests of workers, maintained their public credit, and safeguarded them from the hazards of unemployment and illness. ${ }^{93}$ Certainly, in the major industrial cities, the corporatist principle of guilds formed the universal logic for economic, social, and political organizations, from cradle to grave, rivalled only by family and kinship structures. Crafts thus played a key role at "all stages of human life" for many city dwellers. ${ }^{94}$ Guild charity was yet another expression of the craft as a brotherhood of honest work in the Netherlands, even if, as elsewhere in medieval Europe, its impact in the sense of systematic poor relief was often minimal. ${ }^{95}$ Only a small percentage of the poor enjoyed its benefits, although in times of acute hardship alms could increase. English guild almshouses accommodated only a symbolic number of residents, and the situation was probably no different in the Low Countries. ${ }^{96}$ Yet, charity was an essential function of medieval craft guilds. ${ }^{97}$ Assistance was not the sole object; it also strengthened internal solidarity and enhanced the guild's

92. See also Bart Ramakers, Spelen en figuren. Toneelkunst en processiecultuur in Oudenaarde tussen Middeleeuwen en Moderne Tijd (Amsterdam, 1996).

93. Rosser, "Crafts, Guilds", pp. 27-30.

94. Stabel, "Guilds", pp. I88-192.

95. See Miri Rubin, Charity and Community in Medieval Cambridge (Cambridge, 2002).

96. Carole Rawcliffe, "Dives Redeemed? The Guild Almshouses of Later Medieval England", The Fifteenth Century, 8 (2008), pp. 5, I9; Wim Blockmans and Walter Prevenier, "Armoede in de Nederlanden van de I4de tot het midden van de I6de eeuw. Bronnen en problemen”, Tijdschrift voor Geschiedenis, 88 (1975), pp. 501-538.

97. As demonstrated by Matthew Davies, "The Tailors of London: Corporate Charity in the Late Medieval Town", in Rowena E. Archer (ed.), Crown, Government and People in the Fifteenth Century (Gloucester, 1995), pp. I6I-190. 
public reputation..$^{9}$ But the primary purpose of guild charity was to reinforce the brothers' intense communal life based on their shared work. ${ }^{99}$ Providing or denying charity to individuals created communities. ${ }^{100}$ The fruits of every guild brother's work paid for charity, and it was reserved for those genuinely unable to perform labour. Guildsmen often even thought it shameful to resort to sources of charity outside their corporation, such as the parish poor tables. ${ }^{\text {IOI }}$

In I 547, the Antwerp bag carriers' guild decreed that an allowance "from the common box" would be given for "consolation and comfort" to members who became sick or disabled and incapable of supporting themselves "as a result of their heavy labour and painful efforts". ${ }^{102}$ In the introduction to a I 556 charity by-law, the Antwerp old clothes sellers' guild disclosed their concern that there was much "secret poverty" in the organization. The "feeble poor of the guild", or "shamefaced housebound poor", were a select group, entitled to the resources of the guild's bussen, mutual aid boxes, which were fairly common by the thirteenth century. Yet some smaller guilds did not have bussen, and sometimes not all guild members contributed. The larger textile guilds often standardized contributions in an established system of solidarity. The I 303 statutes of the Bruges shearers, for instance, stated that each master had to give a penny a week and each journeyman half a penny. ${ }^{103}$ Town governments were initially suspicious that the funds might be used to buy weapons, or finance strikes, ${ }^{104}$ which certainly did happen, as there was no fundamental contradiction between using their common resources for those activities and giving charity to guild brothers. All of this served their communities of labour.

Guild laws also emphasized that charity recipients had to act morally. The I 493 Antwerp stonemasons' box rules specified that the "box masters" had to visit sick artisans to ensure that they were entitled to their allowances. The rules forbade the sick from begging before churches, or visiting inns. If the member's accident resulted from alcohol or recklessness, he would not receive aid. ${ }^{105}$ As their Bruges colleague Anthonis had also warned, not

98. Benjamin R. McRee, "Charity and Guild Solidarity in Late Medieval England”, Journal of British Studies, 32 (1993), p. 198.

99. Lis and Soly, Worthy Efforts, p. 108.

100. See Katherine A. Lynch, Individuals, Families and Communities in Europe, I200-1800 (Cambridge, 2003); Robertson, The Labourer's Two Bodies, pp. 24-26, 80-82.

Iог. Hadewijch Masure, “'Eerlycke huijsarmen' of 'ledichgangers'? Armenzorg en gemeenschapsvorming in Brussel, I $300-1640$ ", Stadsgeschiedenis, 7:I (20I2), p. 9.

I02. "overmits den zwaeren aerbeid ende zuerder pynen"; "ter laeffenisse ende troeste": Huys, Duizend jaar mutualiteit, p. 3.

I03. Ibid., pp. 65, 68-69, 41; Espinas and Pirenne, Recueil, I, p. 542.

104. Wyffels, De oorsprong, p. 97.

ıо5. Huys, Duizend jaar mutualiteit, pp. I6-17. 
leading a decent life of work and Christian duties could lead to "being imprisoned in the poor house" while only "realizing this in poverty in old age", when it was too late. ${ }^{106}$ Only honest incapacitated workers and their families deserved guild charity - yet another demonstration of the central moral and ideological value of labour.

\section{AN IDEOLOGY CENTRED AROUND LABOUR FOR THE COMMUNITY}

During the early modern period and especially from the eighteenth century onwards, European artisans increasingly started writing texts with autobiographical characteristics. When these authors occasionally commented on their own work, they always strongly linked it with self-worth and personal identity. ${ }^{107}$ The Bruges master stonemason Anthonis de Roovere together with some Italian contemporaries of the mid-fifteenth century ${ }^{108}$ can be considered among the earliest examples of such men, reflecting on the value of obedience and love at a construction site. Indeed, he recorded that he was working in Ostend while he composed the poem, performing his Christian duty of obedient labour, maybe for a private client or a church, or perhaps as a subcontractor for a wealthier master.

With his own humble but skilled work and by ensuring that the journeymen and apprentices under his tutelage obeyed him, Anthonis contributed to his community, a central ideological preoccupation for an artisan. Not only were his body, and the bodies of his guild brothers and their families, reproduced by their labour, so too was the entire body of society. In the master mason's ideology, his diligent and meticulous work was a sign of both his humility and his pride, a sentiment also discernible in the motto of another highly skilled and cultured Bruges master, the genius Jan van Eyck, who inscribed on his self-portrait "As best as I can" (Als ich can) - that is how the artisan should work. ${ }^{109}$

These are not isolated cases. Groups of urban artisans with their own political and economic aspirations can be clearly delineated in the Netherlands from the twelfth and certainly from the late thirteenth century onwards. They did not form a class in the Marxist sense, but bound by the

I06. Mak, De gedichten, p. 254 .

107. James S. Amelang, The Flight of Icarus: Artisan Autobiography in Early Modern Europe (Stanford, CA, 1998), pp. 44, I 20.

108. Examples in ibid., pp. 277, 293, 307, 31 5, 317, 321 , 325.

I09. Jamie L. Smith, "Als ich can: How Jan van Eyck Extended the Vernacular from Dutch Poetry to Oil Painting", in Joost Keizer and Todd M. Richardson (eds), The Transformation of Vernacular Expression in Early Modern Arts (Leiden, 2012), pp. 273-302, offers an elaborate intellectual genealogy of this motto. However, I feel that the older interpretation of Elisabeth Dhanens, Hubert en Jan van Eyck (Antwerp, I980), pp. I80-18 I, on Van Eyck's awareness "of his own skills and limits" reflects its most straightforward meaning. 
skilled work common to them and organized in corporative organizations they certainly had a distinctive self-image and an evolving political vision and economic programme. Their ideological discourses are ever more clearly expressed in the sources they produced from the fourteenth century onwards as a self-confident group in urban society with a common political trajectory that shaped a self-conscious "guild ideology".

They often managed to obtain considerable autonomy and, in comparison with most other European regions, a remarkable and durable degree of political power; "honest work" organized in guilds was central to the constitution of urban culture. Even though there were socioeconomic differences among guildsmen and geographical and chronological variations in the degree of political power they wielded, the shared ideology of the late medieval Low Countries posited a community of brotherly love and charity centred on the value of skilled labour, and that urban artisan communities possessed freedoms and privileges and should have a say in governance, so that each man could maintain his livelihood and feed his family.

Jean-Pierre Sosson's observations on the often considerable gap between the "norms" of guild discourse and the "reality" of firm statistical data on standards of living, the degrees to which crafts were open to new members, the vested interests of the in-group, and the internal socioeconomic differences between members were pioneering work in the study of later medieval guilds. ${ }^{10}$ Even if it has become accepted that the ideological discourses produced by guilds in their records should certainly not be taken at face value in socioeconomic or political investigations, they still cannot simply be discarded as out of touch with any kind of reality. Today, no scholar would contest the value of studying these discourses for their performative ideological power.

While Cerutti primarily emphasized the instrumentalist use of these guild languages, and Farr considered them mostly a means for constructing a cultural group identity, I tend to prefer Kaplan's emphasis on guild ideology as a way of representing and affirming the social position of artisans within their town and society at large. However, it must again be emphasized that the later medieval Low Countries, and notably the major towns in Flanders, Brabant, Liège, and Utrecht, were rather exceptional when it came to the guilds' power within the specific political economy of urban artisanal production and commercial capitalism. As a result, the guild ideology of the medieval Netherlands was also a deeply political one. Even if there was internal strife and often a considerable gap in socioeconomic status between the upper and lower layers of some crafts - although certainly less

I Iо. First formulated in Jean-Pierre Sosson, "La structure sociale de la corporation médiévale. L'exemple des tonneliers de Bruges de I 350 à I 500", Revne belge de Philologie et d'Histoire, 44:2 (1966), pp. 457-478; idem, Les travaux publics de la ville de Bruges, XIVe-XVe siècles. Les matériaux. Les hommes (Brussels, 1977), pp. 225-260. 
pronounced than in most European regions during the better documented and better studied early modern period - it was the unified political power of the guilds based upon the central value of their labour that was most reflected in this discourse.

As de Roovere reflected on the meagre allowances of porridge and black bread given to elderly artisans, he recognized the tension between the normative discourse that craftsmen were rewarded for their honest work and the grim reality of an old age dependent on charity. Economic fluctuations and social polarization as a result of capital accumulation created conditions that often conflicted with the ideological language of brotherly love and charity, even when guildsmen stood shoulder to shoulder to defend their privileges. For all his complaints, Anthonis leans towards acquiescence and trust in God rather than defiance. "The powerful have often heard my name", the mason writes, "but this has yielded few results" - in the end, the artisan can save himself only through his work. ${ }^{\text {II }}$ But, as he wrote in another poem, "the poor and the rich are equally unfree", and both will have to face God's final judgement. ${ }^{\mathrm{II}}$ It is clear that while the guildsmen of the late medieval Low Countries, in a time and region where guild power was at its peak, believed that their hard work would be rewarded in the hereafter, this did not stop them from expressing their worldly views in a great number of documents produced in the context of their collective organization and actions. They make up a monumental body of self-conscious discourse on the ideological value of labour in pre-industrial urban society.

\section{TRANSLATED ABSTRACTS \\ FRENCH - GERMAN - SPANISH}

Jan Dumolyn. "J'y ai réfléchi pendant le travail, à Ostende." Main-d'œuvre artisanale urbaine et idéologie de la métier dans les Pays-Bas du bas Moyen Âge.

À partir du douzième et sans nul doute du treizième siècle, un groupe social d'artisans dotés de leurs propres aspirations politiques et économiques peut être clairement délimité dans des villes néerlandaises. Unis par un travail spécialisé commun, ils formèrent un groupe distinctif avec une image propre ainsi qu'une vision politique et un programme économique en développement. Leur "idéologie de la métier" s'exprima avec de plus en plus de clarté dans les sources qu'ils produisirent à partir du quatorzième siècle en tant que groupe conscient de son identité dans la société urbaine. La main-d'œuvre, du moins lorsqu'elle s'organisa dans des structures de guilde, fut la pierre de taille de la vie communautaire, des expériences culturelles et de l'éthique pratique. Même s'il y eut des différences socioéconomiques entre les membres des guildes et de nombreuses variations 
géographiques et chronologiques dans le degré de pouvoir politique qu'ils exercèrent, l'idéologie artisanale dans les Pays-Bas du bas Moyen Âge reposa sur la notion d'une communauté d'amour fraternel et de charité, centrée sur la valeur du travail qualifié.

Traduction: Christine Plard

Jan Dumolyn. "Die Idee kam mir bei der Arbeit, in Ostende." Städtisches Handwerk und die Ideologie der Zünften im niederländischen Spätmittelalter.

Möglicherweise vom I 2., sicherlich aber vom I 3 . Jahrhundert an lässt sich mit Bezug auf die niederländischen Städte und in einem deutlich bestimmten Sinn von Handwerkern als einer sozialen Gruppe mit eigenen politischen und wirtschaftlichen Bestrebungen sprechen. Verbunden durch gemeinsame Facharbeit, bildeten die Handwerker eine eigenständige Gruppe mit einem Selbstbild, sich entwickelnden politischen Vorstellungen und einer wirtschaftlichen Programmatik. Ihre "Zünftenideologie" kommt deutlich in den Quellen zum Ausdruck, die die Handwerker ab dem i4. Jahrhundert produziert haben - als selbstbewusste Gruppe in der städtischen Gesellschaft. Die Arbeit war, jedenfalls wenn sie in Gilden-Strukturen organisiert war, der Eckstein des Gemeinschaftslebens, kultureller Erfahrungen und der praktischen Ethik. Zwar gab es sozioökonomische Unterschiede zwischen den Gildenmitgliedern sowie ein geografisches und chronologisches Gefälle im Ausmaß ihrer politischen Macht, doch war das Ideal der Handwerkerideologie in den spätmittelalterlichen Niederlanden das einer von Bruderliebe und Barmherzigkeit gekennzeichneten Gemeinschaft, die den Wert qualifizierter Arbeit zum Mittelpunkt hatte.

Übersetzung: Max Henninger

Jan Dumolyn. "Pienso en ello mientras trabajo, en Ostende." El artesanado urbano y la ideología gremial en los Países Bajos en el periodo tardo medieval.

Desde el siglo XII y con toda seguridad desde el siglo XIII en adelante, podemos delimitar la existencia en las ciudades de los Países Bajos de un grupo social de artesanos con sus propias aspiraciones políticas y económicas. Ligados por las características comunes de un trabajo cualificado se configuraron como un grupo distintivo, con una imagen propia y desarrollaron una visión política y un programa económico. Su "ideología gremial" se manifiesta claramente de forma creciente en los documentos que produjeron desde el siglo XIV en adelante, como un grupo consciente de sí mismo en el seno de la sociedad urbana. Su trabajo, desde luego organizado a partir de las estructuras gremiales, se convirtió en la piedra angular de una vida en comunidad, de experiencias culturales y de éticas prácticas. Incluso aunque existieran diferencias socioeconómicas entre los agremiados y numerosas variaciones geográficas y cronológicas respecto al grado de poder político que tenían en sus manos, el ideal de una ideología artesana en los Países Bajos tardo medievales se componía de una comunidad de amor fraternal y de caridad centrada en el valor del trabajo cualificado. 